\title{
STRATEGY TRAINING FOR MANAGING COOPERATIVE FINANCE IN SOUTH MERUYA VILLAGE
}

\author{
Aty Herawati \\ Universitas Mercu Buana Jakarta, Indonesia.
}

\begin{abstract}
This training is an activity related to the economic empowerment of the community through cooperatives in partner villages. In order to support community economic empowerment, the counseling and training on managing business units in the scope of cooperatives is very precise. Cooperatives can be interpreted as a business entity that has members in which each member has the duties and responsibilities. Each member has the same voting rights in every decision to be taken. The cooperative financial management is very important in the management of cooperatives. How to manage finances on a cooperative will be delivered to this training. Therefore, this activity will give mentoring and training to the managers of cooperatives in particular and the general public so that the partner will be able to implement in the activities of managing the cooperative finances. The expected outcomes from this activity are: (1) Knowledge development in managing the finance of cooperatives in South Meruya village. (2) The formation of social groups concerned to develop cooperatives in South Meruya village.
\end{abstract}

Keywords: Cooperative Finance, Welfare, Community.

\section{INTRODUCTION}

\section{Background}

In the facing of an increasingly open and competitive market mechanism, cooperatives in Indonesia should increase competitiveness such as making product and service innovations, human resource development, technological enhancement, financial management and expanding the marketing area. This is done in order to compete with the local and foreign products that increasingly flood the industrial and manufacturing centers in Indonesia.

The development of cooperatives in Indonesia is still faced with various issues, causing weak competitiveness of imported products. Another problem is the trade liberalization, such as the enforcement of ASEAN China Free Trade Area (ACFTA), which has effectively occurred since 2010 and MEA (Asean Economic Community) since 2015. Based on research and analysis of cooperative experts in Indonesia, it is still less able to compete, for example related to product quality, price, market readiness and the unclear import product map. In terms of products, cooperatives must determine the right product to be marketed. Products that are made must be innovative and attractive to compete in the global market.

Readiness of cooperatives in the face of globalization is the responsibility of all nation elements including educational institutions, in this case university. It is necessary to do cooperative empowerment in the effort to strengthen cooperatives as national economic fundamentals. One of the community empowerment is in the form of socialization that gives understanding of business competition in globalization and strategy to compete so that the community can understand the substance of the implementation of the strategy in developing cooperatives in order to actualize the independence of the Indonesian economy.

The financial strategy in this case means to meet the needs of the business capital and control the finances so that their availability and designation are in accordance with the things that have been planned beforehand. Controlling money out, does not mean to be stingy, but we can consider carefully, fervently and openly, any activity that will be financed. Whether the activity is something that this cooperative needs, or just a desire that still can be postponed.

Managing the finance of cooperatives seems so simple, but in practice many people are not able to manage them properly. This is not a matter of the big or small income received, but rather how to spend the money in a direction according to the allocation based on the priority scale. Budget allocation and expenditure in this simple scale cooperative company, if it is not managed properly, it will bring the cooperatives to the famous terminology of dig a hole close a hole.

Cooperative financial management is a way to manage cooperative finance regularly and carefully through the stages of planning, implementation, and supervision / assessment. This management skill is very important possessed by every cooperative, because the sustainability of the cooperative depends on how to manage the 
finance of the cooperative. Without the knowledge of financial management, especially financial planning, the sustainability of the cooperative is difficult to guarantee.

\section{Problem Identification $\backslash$}

South Meruya village has human resources that actually can be utilized to improve the ability in fulfill the needs of its life, however there are problems that can be identified as follows:

1. Lack of understanding of the cooperative managers about finance in a cooperative.

2. Lack of understanding of the cooperative managers about managing cooperative finance strategies.

\section{LITERATURE REVIEW}

According to Ross et al (2010) the management of business finance is included three things, there are management of working capital, capital budgeting and capital structure. Based on this approach, the new business entity that will be established need to be adjusted into capital budgeting, management of working capital and capital structure.

Based on the concept and the community empowerment application, in fact, the empowerment strategies have the direction: (1) Community empowerment. (2) Implementation of autonomy and delegation of authority in development management that develops community participation, and (3) Modernization through changes in socio-economic structures, cultural and political structures that are sourced to community participation. Meanwhile, according to Mubyarto (1996), the economic development of community can be seen from three sides, namely: first, creating circumstances that enable the potential of society to thrive, second, strengthening the economic potential that communities have to capitalize on economic opportunities and third, Protecting people and preventing unbalanced competition.

Procedures for managing business finances for prospective cooperative members. Discussion related to capital budgeting, management of working capital and capital structure.

1. Through Capital Budgeting, participants identified the durable goods needed to support the operation of this production cooperative. The goods such as table chairs, cookware, jars, tableware and so on whose details will be discussed at the time of the first meeting of cooperative formation. Durable goods to be purchased and become cooperative assets are kept to a minimum so that their use can be optimal.

2. After the information on the assets is durable and investments needed are known, the next step is the management of working capital. This activity is related to two accounts of the balance sheet, i.e. current assets and current debt. The component of current assets which is the focus of attention is cash, receivables or bills and inventory of goods. Cash can be derived from member dues, public or government contributions, repayment of receivables and sales proceeds. Cash withdrawal related to the purchase of fixed assets, purchase of raw materials and expenses for other expenses. Receivables or bills occur due to credit sales. Stock items related to the purchase of raw materials or the value of the finished goods are not sold. Components of current debt, such as employee wages and debt to suppliers.

3. Based on the information about capital budgeting and the management of working capital, the Capital Structure can be implemented by knowing the size of funds needed to operate the cooperatives. The source of funds for this activity can be grouped into the own capital and debt. The group's own capital can be derived from member dues, governmental or private contributions. Debt can be derived from loans, debts to suppliers or other forms of lending.

\section{TARGET AND OUTCOME}

\section{Target}

The general target to be achieved through this activity is to increase the knowledge and ability to manage cooperative financial management. In order to manage the cooperative finance professionally, the cooperative managers needs to know a few key concepts about the cooperative financial management. There are two main concepts about SME financial management that must be known, namely about the balance sheet and loss / profit and also cash flow management.

In particular, the target is to be achieved through the following stages:

1. Understand cashflow. Cashflow is the flow of money that flows from us to get the money, save it, develop it and spend it regulary, wisely and in discipline. Knowledge of cash flow must be known so that cooperative finance will not be chaotic and monitored.

2. Understand revenue. Revenue is an activity that aims to include money or property. Usually, income can be gained from two activities, namely the sale of products or services and investments. Investment result are obtained from activities in developing money and property in various ways. There are several ways that can 
be invested, namely deposits, property, stocks, business results, mutual funds, bonds, and others. All of revenues are usually stored in cash or in banks.

3. Understand Expenditure. Expenditure means all activities resulting in reduced money.

4. Understand Investments. Investment as a source of cooperative income.

5. Understand to the wealth and income statement. If someone asks, what is your current net worth? what percentage growth of your wealth compared to previous year? What is your income/surplus of the month? What is the percent increase/decrease in your income/surplus of revenue this month compared to the same month in the previous year? Nearly many are not ready to give an immediate answer. This is because most of the cooperatives do not have a record/report of wealth and profit loss in cooperative every period $/ \mathrm{month}$.

\section{Outcome}

The outcomes are as follows:

1. Increased in the knowledge of the surrounding community, especially the manager of cooperatives on managing cooperative finance.

2. The desire to manage the cooperative finance.

3. Outcome training results, registration of cooperative expenditure.

Table 1. Outcome Target Plan

\begin{tabular}{lll}
\hline No & Types of Outcome & $\begin{array}{l}\text { Performance } \\
\text { Indicator }\end{array}$ \\
\hline 1 & Scientific publications in journals/proceedings & No \\
\hline 2 & Publications in mass media (print / electronic) & No \\
\hline 3 & Increased the turnover of the partner engaged in the economic field & No \\
\hline 4 & Increased the quantity and quality of products & No \\
\hline 5 & Increased understanding and community skills & Yes \\
\hline 6 & Increased tranquility/Public health (general community partners) & No \\
\hline 7 & Services, models, social engineering, systems, products/goods & Yes \\
\hline 8 & Intellectual property rights (patents, simple patents, copyrights, trademarks) & No \\
\hline 9 & Textbooks & No \\
\hline
\end{tabular}

\section{IMPELEMENTATION METHOD}

Impementation of activities

Praise the Presence of Allah SWT, because this activity has been implemented on:

Day/date $\quad$ : $\quad$ Friday, $5^{\text {th }}$ July 2019

Time : $\quad 13.30-16.00$ WIB

Place : $\quad$ South Meruya village, Kembangan sub-district. West Jakarta.

Target

The target group for this training material is the people of South Meruya Village, which is not far from the campus of Mercu Buana University. The number of invited participants is 30 consisting of cooperative managers, PKK administrators and the community in various RTs and RWs in Meruya Selatan.

\section{Method of Activity}

The methods to be used to achieve activity objectives can be described as follows:

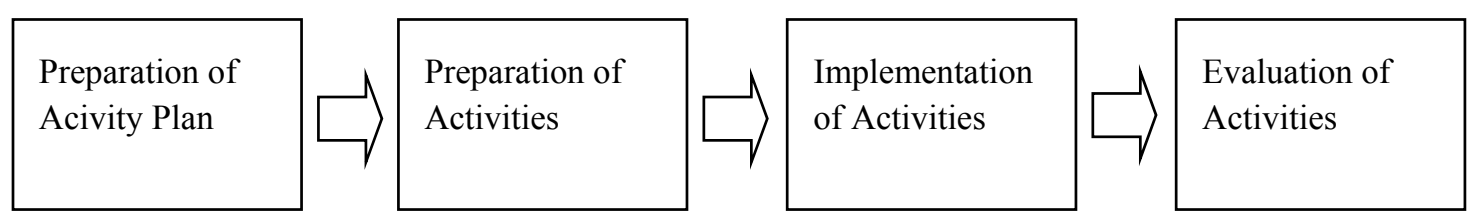

Figure 1. Method of Activity 
Description:

1. Preparation of activity plan

a. Coordination with related parties

b. Make an activity plan

2. Preparation of activities

a. Make invitations for participant

b. Contact and ensure the speaker

3. Implementation of the activities

Training of the strategy in managing the cooperative finance in South Meruya village

4. Evaluation of the activities

The evaluation that will be carried out relates to:

a. Preparation of activities

b. Coordination with related parties

c. Materials and speakers

d. Attendance of participants

e. Equipment and administration

\section{RESULT AND DISCUSSION}

\section{Implementation of the activities}

This service activity is held in the context of routine activity of the community service activity as one of the Tri Darma of higher education. This activity is well-maintained and timely according to what is expected. Number of participants attendance as many as 30 people.

With the rundown of the activity as follows:

Table 2. Rundown of Activity

\begin{tabular}{llll}
\hline NO & TIME & TOPIC & EXECUTOR \\
\hline 1 & $13.30-13.45$ & Registration & Committee \\
\hline 2 & $13.45-14.45$ & Strategy Training Managing Cooperative Finance & Dr. Aty Herawati \\
\hline 3 & $14.45-16.00$ & Case study strategy for managing cooperative finance & Fitria Utami \\
\hline
\end{tabular}

\section{Activities Material and Equipment}

Training materials are distributed to participants regarding theoretical and practical material. Training materials presented in the form of power points and the case of managing financial cooperative strategies. The training material is explained interactively in the form of class presentations and discussions. The implementation of the cooperative financial managing strategy is discussed in groups.

\section{Evaluation of Activities}

a. Through the attendance list, it is found that there were 15 participants

b. Presentation of training materials is carried out according to the training schedule.

c. From the recapitulation of the training evaluation sheet, it is known that participants stated that the training is very beneficial to improve understanding related strategies in managing cooperative finances.

The driver's success factor for this activity are:

a. Good communication between the community service teams.

b. Good cooperation between the community service team and participants.

c. The enthusiasm of the participants in following the training until completion.

The obstacles factor:

a. The training cannot only be done in one day because there are many participants that still do not understand about the strategy in managing the cooperative finance.

b. Limitations of the time and funds 


\section{Result and Discussion}

This service activities done by means of field surveys, interviews, and direct practice. Based on interviews with several residents, they urgently need strategy training managing cooperative finance to increase their knowledge and technical skills as well as to gain the ability to implement cooperative finance strategies.

Regarding the identification of the issue that has been addressed, the following issues are expected:

1. Provide understanding and knowledge about managing cooperative financial strategy

2. Providing training and technical skills to the community regarding the implementation of the strategy to managing cooperative finance.

3. Provide simulation implementation process of managing cooperative finance

\section{CONCLUSION AND SUGGESTION}

\section{Conclusion}

a. Overall, the training participants are dominated by individuals who have a creative spirit. Participants are able to express their ideas and opinions, but it takes time for good self-adjustment in training situations. The participants' thinking patterns are quite open and flexible.

b. The atmosphere of the class is quite lively. The participants are creative and tend to dare to express their opinions openly, both in group discussions and individually.

c. Overall, the participants expressed that the training activity was interesting, many new things gained and learned during the activities. Training materials are very useful in sending participants to better understand the strategy of managing a cooperative finance.

d. This activity can be used as a means of communication, friendship and socialization of the Management Postgraduate Program at Mercu Buana University to the public, and also as a manifestation of the social responsibility of Tri Darma higher Education.

\section{Suggestion}

The duration of training activities can be extended up to two days. In two days, the implementation of the activities is expected that the material and practice related to implementing the strategy of managing the financial cooperatives in order to improve the environmental quality can be delivered more optimally.

\section{REFERENCES}

Fisher, I, The Theory of Interest, New York, Macmillan, 1930

Husnan. S, “ Pembelanjaan Perusahaan, dasar-dasar manajemen Keuangan”, Liberty Yogyakarta, 1989.

, "Dasar-dasar Teori Portofolio", Liberty Yogyakarta, 1989.

Kementerian Koperasi dan Usaha Kecil dan Menengah Republik Indonesia, 2018. Peraturan Menteri Koperasi dan Usaha Kecil dan Menengah Republik Indonesia, Nomor 09 tahun 2018 tentang Penyelenggaraan dan Pembinaan Koperasi (diakses tanggal 23 November 2018) , tidak bertanggal. Cara Mendirikan Koperasi \& Langkah - Langkah Mendirikan Koperasi

(http://kementeriankoperasi.com/cara-mendirikan-koperasi-langkah-langkah-mendirikan-koperasi/, diakses tanggal 23 November 2018)

Riyanto. B, "Dasar-dasar Pembelanjaan Perusahaan”, BPFE Yogyakarta, 1989

Ross, A. Stephen, Randolph W. Westerfield dan Jeffrey Jaffe, 2010. Corporate Finance, Edisi ke 9, McGraw Hill International Edition, New York

Sekretariat Negara Republik Indonesia, 2012. Undang - Undang Republik Indonesia Nomor 17 tahun 2012 tentang Perkoperasian (diakses tanggal 23 November 2018) 